\title{
Contracts, Hold-Up, and Exports: Textiles and Opium in Colonial India
}

\author{
Rachel E. Kranton and Anand V. Swamy
}

December 2006

Abstract: Trade and export, it is argued, spur economic growth. This paper studies the microeconomics of exporting. We build a heuristic model of transactions between exporters and producers and relate it to East India Company operations in colonial Bengal. Our model and the historical record stress two difficulties: the exporter and its agents might not uphold pricing agreements, and producers might not honor sales contracts. The model shows when procurement succeeds or fails, highlighting the tension between these two hold-up problems. We analyze several cases including the East India Company's textile venture, the famous Opium Monopoly, and present-day contract farming.

*Kranton: Department of Economics, University of Maryland, College Park, MD 20742; Swamy: Department of Economics, Williams College, Williamstown, MA 01267. We thank an anonymous referee for comments, and Joe Altonji, Cheryl Doss, Doug Gollin, Santhi Hejeebu, participants at the Yale Development Lunch, ESSET 2006, 75 Years of Development Economics Conference at Cornell, Third Mini-conference in Development CIRPÉE/LAVAL, World Bank Microeconomics of Growth conference, seminars at University of Arkansas, Columbia University, Drexel University, MIT, and the Institute for Advanced Study for helpful suggestions and discussion. We thank Natalia Perez for her research assistance. Rachel Kranton thanks the Institute for Advanced Study, Princeton's Research Program in Development Studies, and the National Science Foundation for support. 


\section{Introduction}

Many economists and policy makers hold that export and trade spur economic development. With globalization, there is potential to export goods to far-off markets, and many see trade as a way to raise incomes in the developing world. Yet how is this export accomplished? How can local production reach the global marketplace? What contractual problems do exporters face? This paper examines these questions.

We consider the microeconomics of export procurement. The paper builds a heuristic model of transactions between exporters and local producers. We relate the model to the operations of a large multi-national company, the East India Company (EIC), whose records provide a rich source of information on problems of contracting for export. We focus on a venture that is especially well-documented: textile procurement in Bengal in the second half of the $18^{\text {th }}$ Century. ${ }^{1}$ Textiles, produced at home by weavers dispersed across the countryside, were the Company's most important export to Europe. ${ }^{2}$ The Company primarily procured these textiles using the "Agency System," where the EIC hired local employees - agents - to transact with weavers. Typical agreements with weavers specified a loan for working capital, the quality and quantity of cloth to be produced, and quality-contingent prices. But the system did not work so well. It was fraught with "corruption" - or opportunistic behavior - on the part of the agents, the weavers, and officials of the EIC itself.

We build a model of this procurement system and highlight two problems we see throughout the historical record. Agents often did not uphold pricing agreements and cheated the weavers, and weavers often sold output to other buyers and thereby did not repay their debts. Our analysis shows the difficulty of solving both problems at the same time. If the EIC gave the agent more authority to prevent outside sales, it simultaneously gave the agent a greater ability to hold-up the weaver and not pay specified prices. In the history we see that the EIC struggled to find the right balance. The model shows how this balance depends on the market structure, the specialized

\footnotetext{
1 "Bengal" here refers to the regions that eventually became Bangladesh and three states in independent India: West Bengal, Bihar, and Orissa. Our sources include Jones (1918), Marshall (1976), Sinha (1956), Wright (1961) and, especially, Hossain (1988) and Mitra (1978).

${ }^{2}$ By the 1750 's textiles accounted for more than $80 \%$ of the value of British exports from Bengal (Chaudhury (1995, p. 182)).
} 
nature of the good, and uncertainty over local bargaining between the agent and producer.

The study provides lessons for historical and present-day procurement. The EIC's procurement process is a typical one: there is an advance of working capital or inputs, goods are produced and then delivered at a later date when final compensation is made. If long-term agreements cannot be enforced, the basic setting falls within the general paradigm of incomplete contracting (Grossman and Hart (1986), Hart and Moore (1990), Williamson (1975)). We see this theory come to life in the EIC records. Two parties make specific investments: the company and agent advance funds to a producer, and the producer makes the cloth to the buyer's specifications. The terms of the agreement are difficult to enforce, hence there is potential for opportunistic behavior on both sides. While the general consequences of hold-up are well-known, the closest paper we know to our model is Edlin and Hermalin (2000), which explicitly gives the producer property rights over the output, allowing him to sell to another buyer. ${ }^{3}$ The development literature emphasizes producers who can renege on debt agreements, but a buyer who can renege on an agreement with a producer does not often appear, with Banerji and Duflo (2000) being a notable exception. ${ }^{4}$ To our knowledge there is no analysis of the situation, likely to be quite common, where both problems and outside sales are present.

We present a stylized (one could say reduced form) model of one-time interaction between an exporter and a local producer. We ask when the exporter, its agent, and the producer all have incentives to uphold contract terms. An alternative approach would be a model of repeated interaction. Absent competition, such a model could yield the familiar result that if players are sufficiently patient, gains from trade can be consistently realized. While this may be an accurate description of interactions in some settings, we often do not see such behavior in our study of textile procurement. We will describe competition among buyers and contractual violations by producers, agents, and exporters who do not seem to fear future retaliation and do not seem to be thinking long-term. We elaborate reasons for this outcome in Section IV.

Beyond the EIC's textile venture, we study the (in)famous opium operations and the land

\footnotetext{
${ }^{3}$ Another literature studies problems due to producers' hidden characteristics (e.g. Rauch and Watson (2003)).

${ }^{4}$ Bardhan $(1980,1989)$ provides overviews of this literature. McMillan and Woodruff (1999), Biggs et al. (2002), and Fafchamps (1997) discuss trade credit. There is also an extensive literature on interlinkage as a solution to moral hazard and enforcement problems in credit contracts in agriculture.
} 
tax collection efforts in eastern India, and we study present-day contract farming in developing countries. Our model indicates that successful procurement requires a balance of bargaining power between the agent and the producer. In the textile case, the EIC faced two difficulties in maintaining this balance. First, competition from other buyers gave weavers the ability to sell elsewhere. Second, the EIC was not able to monitor its agents and faced uncertainty regarding the agent's ability to enforce the contract. In later opium operations, both of these problems were less salient. The Opium Agency, initiated by the EIC, was an explicit and declared monopsony/monopoly - all legal poppy cultivation was for the Agency, and sale was only through the Agency. Though there was some smuggling, local producers had fewer outside options. To curb agents' opportunism, the Opium Agency hired personnel and instituted procedures to monitor key transactions with cultivators. We argue these two features were complementary; the monopsony mitigated the hold-up ability of the producer, and monopoly rents from selling a highly lucrative product provided the funds and the incentive to invest in a monitoring system. ${ }^{5}$ Our study of the East India Company's efforts to collect land taxes supports this interpretation of procurement operations. ${ }^{6}$ The Company again relied on local agents, and we see a similar struggle to give agents the right amount of power in their tax collection efforts and dealings with tenant farmers.

Today, many companies use similar systems, called "Contract Farming," to procure products such as coffee, fruit, and other export crops. Exporters advance funds to farmers, and often provide technical assistance. In return, the farmer is obliged to sell the crop to the exporter. We again often see that procurement breaks down. When there are many competing buyers, producers take advances from one company and sell to another. As our model indicates, however, a monopsony could give the exporter too much power, and, unless the exporter can police itself and its employees, opens the door to hold-up of producers. We discuss examples of this outcome as well.

This paper contributes to the study of the role of institutions in economic growth and development. Following Douglass North (1990), economic historians have explored how institutions can foster expanding trade. Greif (1993), a prominent example, shows how a community of traders

\footnotetext{
${ }^{5}$ The Company's own management also became less corrupt. We elaborate below.

${ }^{6}$ The EIC collected land taxes in its role as Diwan of Bengal. See the historical review below.
} 
successfully transported goods from one port to another, despite agency problems. Our study considers how goods make it to port in the first place. Several papers study the internal management of the EIC and other trading companies (e.g. Carlos and Nicholas (1990), Hejeebu (2005)). None of this work focuses on contractual relations with producers, which is our main interest.

The rest of the paper is organized as follows. In the next section we discuss the historical background of the EIC and its textile procurement in Bengal. Section III presents a model of export procurement. Section IV draws on the model and discusses the evolution of the EIC's textile procurement policies, the Opium Agency, and land tax collection efforts. Section V discusses present-day contract farming. Section VI concludes.

\section{The EIC In Bengal and Textile Procurement}

The English East India Company was founded in 1600 with a monopoly on English trade with Europe from east of the Cape of Good Hope to the Straits of Magellan. The EIC operated in many parts of the world, including the American colonies, India, and China. We study operations in eastern India after 1757, when, in the Battle of Plassey, the East India Company defeated the Nawab of Bengal, establishing itself as the dominant political authority. The Company's de facto power gradually became de jure power: after initially operating via client rulers, the Company took control of financial administration and revenue collection in 1765 , formally took over civil and judicial administration in 1772, and eliminated the Nawab's last remaining role, in administration of criminal law, in $1790 .^{7}$ The British gradually established an administrative system. Substantial efforts to curb corruption among top-level (European) employees began towards the end of the eighteenth century, and selection and management procedures were subsequently further improved. To govern a vast and unfamiliar territory the Company relied heavily on Indian

\footnotetext{
${ }^{7}$ After becoming Diwan in 1765, the Company initially left much of the administration, including the judiciary, to the Nawab's officers. This awkward arrangement was abandoned in 1772 when, under Warren Hastings, the first Governor-General, the Company explicitly took over civil and judicial administration. At the outset a civil court, known as Diwani Adalat, was established in each district, headed by the "collector," the Company official in charge of collection of land revenue. Over the next few decades the system was modified repeatedly. In 1773 the collectors were replaced with Indian judicial officers (naibs) whose work was supervised by one of six "Provincial Courts" that were in the charge of Company officials. When the burden on these courts became too great, British officials were again dispersed through 18 mofussil (district) Diwani Adalats which, henceforth, were central to the civil judiciary (Misra $(1959,1961))$.
} 
intermediaries $;^{8}$ effective procedures for their supervision evolved slowly and were consolidated only by the second half of the nineteenth century (Robb (1997)). We will see how the increasing ability to monitor employees and enforce contracts affected the textile, opium, and land tax collection ventures. ${ }^{9}$

We first study the East India Company's cotton textile operations. Textiles were made by weavers using hand-looms in their homes. Weaving was often not a sole occupation but combined with farming, and production was dispersed throughout the countryside. Bengali textiles had several outlets: local consumers, markets in upper India to which Bengal is connected by major rivers, and exports to regions outside South Asia. ${ }^{10}$ By the end of $17^{\text {th }}$ Century, Bengali textiles were very popular in Europe, the "India Craze" of the 1680's being one manifestation. Other European companies including the Dutch, French, and Danish were active in the market. Trade volume was large; Prakash (1976, p. 173) estimates that in the early $18^{\text {th }}$ century Dutch and English textile exports created $75,000-100,000$ jobs. ${ }^{11}$ By the first half of the $18^{\text {th }}$ century, Europe was the major export market. ${ }^{12}$ Besides European companies, local merchants and private traders from Europe, India, and Asia sought to buy cloth. One source was the spot market, where a "ready money" (khush khareed) purchase could be made. A buyer could also advance capital to a weaver for purchase of inputs, including yarn, in return for a commitment to produce for him - an arrangement called dadan. Such arrangements were advantageous to the weaver: he received capital, and he was guaranteed (in principle) a buyer for his product. The buyer was

\footnotetext{
${ }^{8}$ In 1773, there were only 250 officers in the Company's civil service in Bengal. European rank and file soldiers and officers in the Company's army accounted for only 3000 and 500, respectively, in 1769 (Marshall (1976, p. 15)). In contrast, an estimated 20 million people lived in the province of Bengal by the early eighteenth century (Prakash (1976, p. 174)).

${ }^{9}$ After becoming a territorial power in eastern India, the Company itself was increasingly supervised by the government in London which was concerned that Bengal was being mismanaged. As Griffiths (1952, p. 156) puts it, "a trading corporation could no longer be allowed to handle uncontrolled an empire in embryo." The Company's bargaining position was also weakened by its dependence on the government during financial crises. The India Act of 1784 set up a Board of Control to supervise administrative, revenue, and political decisions of the Company. The Board of Control's power grew steadily, and the Company's privileges were gradually eliminated: in 1813 it lost its monopoly trading rights with Europe; after 1833 its commercial operations were ended and the Company was a purely political and administrative entity in India (the opium trade, a partial exception, is discussed in Section IV.B.); finally, in 1858, after a large-scale rebellion in northern and central India, the British Crown directly took over Indian administration.

${ }^{10}$ Chaudhury (1995, p. 147) lists South-East Asia, West and Central Asia, the Persian Gulf and Red Sea areas, and North Africa.

${ }^{11}$ Prakash (1976, p. 173) provides lower and upper bounds of 75,620 and 99,804. The workforce in Bengal province at this time is estimated at 10 million, one million of whom were in textiles and raw silk taken together.

${ }^{12}$ See Chaudhuri (1978, p. 247).
} 
guaranteed (again, in principle) supply, made to specifications. Timely and assured procurement was particularly important for European companies, whose ships made journeys lasting many months. In its "Contract System" the EIC placed orders with local merchants who advanced capital and procured cloth. In its "Agency System" the Company hired salaried employees in order to deal directly with the weavers.

The EIC predominantly used the Agency System in the period we study, and we describe it here in further detail. The EIC established "factories" - administrative offices - in major towns. ${ }^{13}$ Each factory linked several collection centers, aurung, headed by salaried employees, gumashtas, who served as the EIC's agents. ${ }^{14}$ In the early years, agents posted bonds with the Company. The Company gave agents funds to advance to weavers ${ }^{15}$ and specified the amounts and types of cloth needed and a price schedule. The gumashta would contract with the weaver, advancing the capital in return for specified cloth. If the gumashta received the cloth, he appraised it, paid the weaver, and sent the cloth onward to the EIC's factory. To recover the final product, the gumashta could use coercive measures, which varied in severity over the period we study. The extent of gumashtas' coercive power was a policy decision of the EIC. It is these policies which we will discuss at length in Section IV.

There is considerable evidence that this system was plagued by opportunism of both agents and weavers. Reporting on gumashta corruption, a contemporary observer, Bolts (1772), wrote: ${ }^{16}$

The roguery practiced in this department is beyond imagination, but all terminates in defrauding the poor weaver; for the prices which the company's gomastahs and in confederacy with them, the jassendars [appraisers] fix upon the goods are in all places at least fifteen percent and in some forty percent less than the goods so manufactured

\footnotetext{
${ }^{13}$ Chaudhuri (1978, p. 573) writes: "The term 'factory' at this time merely signified an establishment for the merchants to carry on business from within a foreign country and it is derived from the word 'factor' meaning an agent employed by the principal merchant."

${ }^{14}$ It appears that there was a single gumashta at each collection center. We could not determine the length of time a gumashta typically served nor do we see evidence of tournaments.

${ }^{15}$ The Agency System policy when it was first formulated in 1753 stated:

"The substantial gomastahs approved of by the Board should be employed at the aurungs, giving sufficient security... that they undertake no other than the Honourable Company's business on forfeiture of their wages and allowance, that each gomastah have different musters delivered to him for his guide....that no gomastah....be entrusted with more than Rs. 20,000 at one time..." (Hossain (1988, p. 88)).

${ }^{16}$ Cited by Mitra (1978, p. 50). Though Bolts was likely biased against the EIC, his views on this matter were widely shared, as we will see in Section IV.
} 
would sell in the public bazaar or market upon free sale.

For their part the weavers also often violated agreements, taking advances from the Company but selling to other buyers, as we discuss further below in Section IV.

The EIC experimented with various policies to address these issues. Our analysis shows why solving both problems was a difficult task. The gumashta needed coercive power to secure the sale of the cloth, but this power in turn gave the agent the ability to hold up the weaver. The solution to one contractual problem created the other. We show the workings of transactions in a simple model.

\section{A Model of Procurement}

There is an export good produced using capital, $k$, and labor, $l$. A producer has the skill to produce the good, but no capital. The exporter has the capital to produce the good, but no skill. We normalize the interest rate to zero and set labor costs equal to the quantity of labor used. There is fixed proportions technology, where inputs $k \geq \bar{k}$ and $l \geq \bar{l}$ result in a single indivisible unit of the good. The exporter has value $\bar{v}$ for the good, where $\bar{v}-\bar{k}-\bar{l} \geq 0$ so the good is efficient to produce.

We focus on one producer and one exporter, given there are many other producers and potentially other buyers. We suppose, for simplicity, that other buyers would pay $m \bar{v}$ for the product, where the parameter $m, 0 \leq m \leq 1$, represents the extent of competition. For example, $m$ could represent the extent to which the good is specific to the exporter who provides the capital. For $m=1$, the good is homogeneous, and there are other buyers willing to pay $\bar{v}$ for the output. ${ }^{17}$ We sometimes call $m \bar{v}$ the "spot market price."

\section{A. Exporter-Producer Interaction with No Intermediary}

The producer and exporter, with no intermediary, interact as follows: The exporter announces a price $P$ that it will pay for the good and an amount of capital $k$ to advance the producer.

\footnotetext{
${ }^{17}$ The specificity of the good could be a choice of the exporter or the producer, and the model could accommodate this possibility. The qualitative results would not change.
} 
The producer decides whether to accept the advance and then whether to produce a good. If he produces, the producer decides whether to sell the good to the exporter or to another buyer. The exporter decides whether or not to pay the promised price $P$.

If prices and all other terms are enforceable, the exporter simply sets $P$ to maximize his profits $\Pi=\bar{v}-\bar{k}-P$, subject only to the producer's participation constraint, $P-\bar{l} \geq 0$. The exporter earns the full surplus from exchange.

When the producer's decision to sell to the exporter is not enforceable, the producer could use the capital for another purpose or produce output but sell to another buyer. This is the typical problem studied in the development literature. The promised, and still enforceable, price must then satisfy two incentive constraints: (1) $P \geq \bar{l}+\bar{k}$ so the producer has the incentive to use labor and capital for production; ${ }^{18}$ and (2) $P \geq m \bar{v}$ so that the producer has the incentive to sell to the exporter. The exporter would set $P=\max \{\bar{l}+\bar{k}, m \bar{v}\}$, and its profits are positive if and

only if $m \leq \frac{(\bar{v}-\bar{k})}{\bar{v}}$ and $\bar{v} \geq 2 \bar{k}+\bar{l}$. The competition cannot be too strong so that a high price erodes the exporter's returns, and the value of the good must cover the producer's incentive to use capital for production.

\section{B. The Exporter Hires an Intermediary}

Now let the exporter hire an employee - an "agent" - to ameliorate this enforcement problem. The exporter pays the agent a wage $w \geq 0$. The agent's responsibilities are to advance the capital to the producer, collect the good upon its completion, pay the producer, and deliver the cloth to the exporter. The agent has an outside opportunity to earn $U$, and we now assume $\bar{v}-\bar{k}-\bar{l}-U \geq 0$ so that the good's value exceeds the agent's opportunity cost as well as production costs.

Unlike the exporter, the employee has some capability to monitor the producer and enforce the sale. This capability could derive from several sources. Public policies could grant agents rights in enforcing contracts, e.g., by allowing them to enter homes and seize property. The agent could have his own ability to sanction a producer through social connections, dunning, or violence. We assume the exporter cannot always observe the agent's interactions with the producer, and

\footnotetext{
${ }^{18}$ This incentive constraint is stronger than the producer's participation constraint. Hence, we need work only with the incentive constraint.
} 
the agent, by virtue of his coercive powers, could ultimately pay a price different than $P .{ }^{19}$ The exporter could, however, have some ability to affect the agent's power - either through its own management practices or through its influence on public policy.

We capture the interaction between the agent and producer with a reduced form bargaining model. Outside buyers would pay a price $m \bar{v}$ for the product. We suppose the agent procures cloth and pays the producer $(1-\beta) m \bar{v}$, where $0 \leq \beta \leq 1 .^{20}$ We call $\beta$ the power of the agent. It summarizes the agent's ability to prevent the producer from selling to another buyer, e.g., the ability to monitor the producer or harass and coerce him. ${ }^{21}$ Such mechanisms reduce the producer's return from outside sales. When $\beta$ is low, the agent has little power and must pay the producer close the spot market price to obtain the cloth. When $\beta$ is high, the agent can obtain the cloth from the producer at much lower than the spot market price.

We begin with the simplest case: $\beta$ is exogenous, and it is a known constant value. We later consider the case where the agent's power is random and unknown to the exporter, but the exporter can affect its distribution.

The exporter, the agent, and the producer interact as follows (see Figure). The exporter announces procurement terms - the capital advance to the producer, the final good price $P$, and the agent's wage $w$. If the agent accepts, he gives the exporter a security $Q$ in return for the advance $\bar{k}$, where $Q>\bar{k}$. He then chooses how much capital to forward to the producer. The producer then chooses whether or not to produce. If the product is made, the agent obtains the cloth, giving the producer $(1-\beta) m \bar{v}$. The agent then delivers the output to the exporter, receives $P$, and recovers his security. ${ }^{22}$ If the agent did not forward the capital, he simply returns it and

\footnotetext{
${ }^{19}$ If the agent is able to completely enforce the debt/sales contract, and the exporter can perfectly monitor the agent, we simply return to our perfect enforceability case with the addition of an agent participation constraint.

${ }^{20}$ The agent always obtains the good, as in equilibria of complete information bargaining games. But historically producers often sold to outside buyers. Thus, we have a familiar dichotomy between historical events and "equilibrium" outcomes. We could specify that the agent has only a probability of obtaining the cloth, and this probability is related to his power. This specification would complicate the analysis without changing its basic message.

${ }^{21}$ We could further specify that, beyond recovering the cloth, the agent can extract some capital/cash from the producer. Such a specification would change the producer's and agent's incentive constraints. Hiring the agent would be more valuable to the exporter. The producer would earn less rents, thereby matching some historical accounts. Our qualitative results regarding the balance between agent and producer would again be similar.

${ }^{22}$ We could add an agent's choice to sell the cloth on the spot market rather than to the exporter. In this case, the exporter must set $P \geq m \bar{v}$ to ensure procurement. The outcome, however, is identical, as the exporter ultimately adjusts the wage to extract rents from the agent (see below). In the EIC textile case, Jones (1918, p. 38) mentions the problem of outside sales by the agent, but it is not prominent in the literature.
} 
recovers his security.

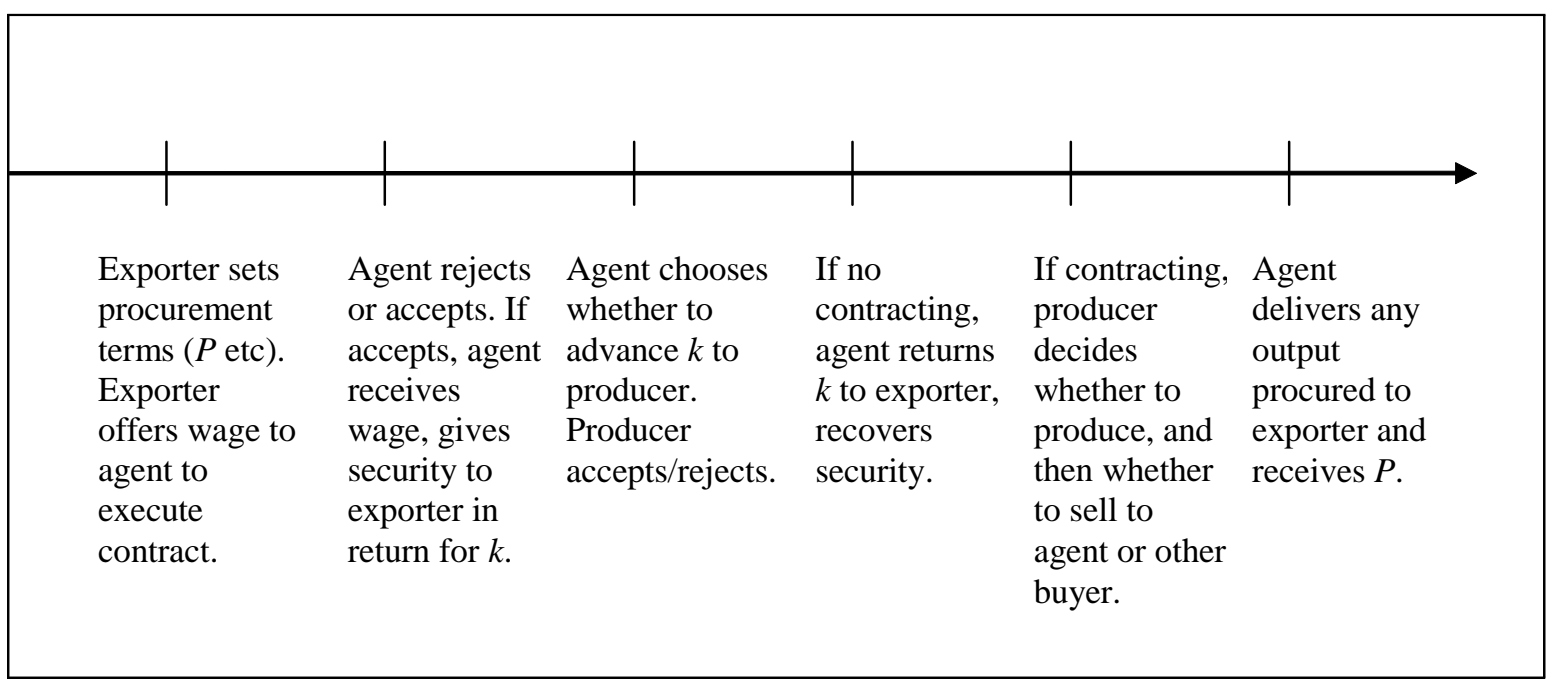

Timing of Interaction between Exporter, Agent, and Producer

Working backwards, we now have three incentive constraints. The producer will produce if and only if his revenues exceed his opportunity cost of capital and labor: ${ }^{23}$

$$
(1-\beta) m \bar{v} \geq \bar{k}+\bar{l}
$$

The agent will forward the capital if and only if he anticipates earning more from procuring cloth than simply returning the capital to the exporter:

$$
P-(1-\beta) m \bar{v} \geq 0
$$

Finally, the agent's total earnings must exceed those in an alternative occupation:

$$
P-(1-\beta) m \bar{v}+w \geq U
$$

The exporter sets $P$ and $w$ to maximize profits $\Pi=\bar{v}-\bar{k}-P-w$ subject to (1), (2), and

\footnotetext{
${ }^{23}$ This incentive constraint is stronger than the producer's participation constraint, hence we will work only with the incentive constraint.
} 
(3). Assuming the agent's participation constraint binding, ${ }^{24}$ we have $P^{*}=(1-\beta) m v, w^{*}=U$, and exporter profits of

$$
\Pi^{*}=\bar{v}-(1-\beta) m \bar{v}-\bar{k}-U
$$

We can now see how procurement depends on the level of the agent's power $\beta$. The power must be high enough so that the exporter earns positive profits, $\Pi^{*} \geq 0$, and low enough so that the remaining constraint, the producer's incentive constraint (1), is satisfied. Setting $\Pi^{*}=0$ gives us a lower bound on $\beta$, and setting (1) as an equality gives us an upper bound on $\beta$ :

$$
1-\frac{\bar{v}-\bar{k}-U}{m \bar{v}} \leq \beta \leq 1-\frac{\bar{k}+\bar{l}}{m \bar{v}}
$$

Procurement thus occurs only when the coercive power of the agent is neither too high nor too low. We first observe that (5) is not satisfied for any level $0 \leq \beta \leq 1$ if $\bar{v}<2 \bar{k}+\bar{l}+U$ or $m<\frac{\bar{k}+\bar{l}}{\bar{v}}$. If the exporter's value is too low, his profits are always negative. If competition is too low to guarantee the producer enough return, he will not produce. When neither is true, procurement will occur if and only if the power of the agent falls within the restricted range: the producer has the incentive to produce, and the agent extracts sufficient surplus to give the exporter positive profits.

Hiring an agent is valuable only at high levels of competition. For low levels, $m \leq \frac{\bar{l}+\bar{k}}{\bar{v}}$, an agent would not only harm profits but shut down procurement altogether. When competition is

high, $m \geq \frac{\bar{l}+\bar{k}}{\bar{v}}$, the exporter earns profits $\Pi=\bar{v}-\bar{k}-m \bar{v}$ when it does not employ an agent and earns $\Pi=\bar{v}-\bar{k}-U-(1-\beta) m \bar{v}$ when it does. The exporter will then hire an agent when $\beta m \bar{v}>U$, the gains from the enforceability capability of the agent exceed the cost of hiring him.

\section{Exporter Can Influence Intermediary's Power}

If the exporter could choose the agent's level of power, it would certainly do so. The exporter would set $\beta$ to exactly meet the producer's incentive constraint (1). The exporter would adjust the price $P$ and wage $w$ to meet the agent's incentive and participation constraints, (2) and (3),

\footnotetext{
${ }^{24}$ Historically, agents were paid a positive wage, and with $w>0$, the participation constraint must be binding.
} 
and thus earn the highest possible surplus.

Most exporters are unlikely to have such control. While an exporter or government could have a target level for agents' power, they are not likely to know exactly how policies translate to facts on the ground. There could be local variability in application of the policies, for example, and variability in the relative bargaining strength of particular producers and agents. A foreign exporter, in particular, is likely to face such uncertainties.

To capture these possibilities, suppose the agent's power is a random variable $0 \leq \widetilde{\beta} \leq 1$ with distribution $F(\beta ; B)$ and density $f(\beta ; B)$, where $0 \geq B \geq 1$ represents the power embodied in the exporter's policies or in public policies. For higher values of $B$, there is always a higher probability that the agent has greater power: for $B^{\prime}>B, F\left(\beta ; B^{\prime}\right)$ first order stochastically dominates $F(\beta ; B)$. To capture individual variability and the inability of the exporter to exactly set the agent's power, assume that any value of the agent's power is possible even for very high or very low $B: f(\beta ; B)>0$ for all $\beta$ and $B$.

For simplicity, suppose the power level is realized after the exporter has contracted with the agent, but before the agent has advanced the capital to the producer. The shock could be realized at other points in time: before the exporter contracts with the agent, after the agent and weaver contract but before production takes place, or after production. Nothing critical hinges on the timing. ${ }^{25}$ We assume the agent and producer but not the exporter observe the realization. ${ }^{26}$

Now when the exporter sets the procurement terms, it does not know whether the two incentive constraints will be satisfied - this will depend on the realized value of the agent's power. Combining (1) and (2), procurement will occur only if the realization of $\widetilde{\beta}$ falls between two bounds:

$$
\left[1-\frac{\bar{k}+\bar{l}}{m \bar{v}}, 1-\frac{P}{m \bar{v}}\right]
$$

which occurs with probability $F\left(1-\frac{\bar{k}+\bar{l}}{m \bar{v}} ; B\right)-F\left(1-\frac{P}{m \bar{v}} ; B\right)$. The agent's participation con-

\footnotetext{
${ }^{25}$ Our timing assumption simplifies the model: the producer need not be risk averse. If some realization occurs after capital is advanced, and the producer is risk averse, similar results obtain.

${ }^{26}$ With this assumption, the exporter cannot make the procurement price contingent on the realized level of the agent's power, which would make the analysis equivalent to the certainty case. This assumption follows our setting where the exporter cannot observe agent-producer interaction and bargaining.
} 
straint becomes ${ }^{27}$

$$
\int_{1-\frac{P}{m \bar{v}}}^{1-\frac{\bar{k}+\bar{l}}{m \bar{v}}}[P-(1-\beta) m \bar{v}] f(\beta ; B) d \beta+w \geq U,
$$

and the exporter's expected profits are

$$
E \Pi=F\left(1-\frac{\bar{k}+\bar{l}}{m \bar{v}} ; B\right)-F\left(1-\frac{P}{m \bar{v}} ; B\right)[\bar{v}-\bar{k}-P]-w
$$

when (6) is met. With the agent's participation constraint (6) binding, for any $B$ the exporter maximizes expected profits $(7)$ by setting the price to $P^{*}=m \bar{v}$, ensuring the agent's incentive constraint is satisfied with probability one, and setting wage $w^{*}=U-m \bar{v} \int_{0}^{1-\frac{\bar{k}+\bar{l}}{m \bar{v}}} \beta d F(\beta ; B),{ }^{28}$ to just meet the agent's participation constraint.

We now see the tradeoff between higher and lower policies, $B$. In the solution, the exporter's expected profits are

$$
E \Pi^{*}=F\left(1-\frac{\bar{k}+\bar{l}}{m \bar{v}} ; B\right)\left[\bar{v}-\bar{k}-m v+m \bar{v} E\left(\beta \mid \beta \leq 1-\frac{\bar{k}+\bar{l}}{m \bar{v}} ; B\right)\right]-U
$$

where $m \bar{v} E\left(\beta \mid \beta \leq 1-\frac{\bar{k}+\bar{l}}{m \bar{v}}\right)$ is the expected gain from enforcement given the producer's incentive constraint is met. Raising $B$ lowers the probability the producer's constraint is met: $F\left(1-\frac{\bar{k}+\bar{l}}{m \bar{v}} ; B\right)$ is decreasing in $B$. But decreasing $B$ could diminish the exporter's expected returns.

There is an additional effect of the policy $B$ if the exporter is constrained to set a particular price $\bar{P}{ }^{29}$ We will discuss such constraints on the EIC below. The probability the agent's incentive constraint is met is now $1-F\left(1-\frac{\bar{P}}{m \bar{v}} ; B\right)$, and the exporter's expected profits are

$E \Pi^{*}=\left[F\left(1-\frac{\bar{k}+\bar{l}}{m \bar{v}} ; B\right)-F\left(1-\frac{\bar{P}}{m \bar{v}} ; B\right)\right]\left[\bar{v}-\bar{k}-m v+m \bar{v} E\left(\beta \mid 1-\frac{\bar{P}}{m \bar{v}} \leq \beta \leq 1-\frac{\bar{k}+\bar{l}}{m \bar{v}} ; B\right)\right]-U$

\footnotetext{
${ }^{27}$ For ease of exposition, let $F$ be differentiable.

${ }^{28}$ This solution is consistent with $w>0$ (agent's participation constraint is binding) when $\frac{\bar{v}-\bar{k}}{\bar{v}} \geq m$.

${ }^{29} \mathrm{~A}$ price constraint would affect the problem only if $\bar{P}<m \bar{v}$.
} 
Increasing $B$ now increases the probability the agent's incentive constraint is met, decreases the probability the producer's incentive constraint is met, and affects the expected rents the agent can extract from the producer. ${ }^{30}$

Hence, when choosing its policies, the exporter will strive to find the right balance between the agent's coercive powers and the producer's incentives.

\section{EIC Operations: Textiles, Opium, Land Taxes}

\section{A. Cotton Textiles}

In its cotton textile venture, we argue, the EIC was largely unable to strike the right balance. The EIC was still a "young" regime: a small group of Englishmen was governing a large, newly acquired territory, with an unfamiliar language. Crime and banditry were rampant. The Company relied on local intermediaries, and it was unable to monitor them well. Corruption among the EIC's upper management made oversight even more difficult. The EIC was also likely constrained in its choice of procurement price. In the 1720's and 1730's the Court of Directors in London began to suspect that officers in India were overstating the prices they paid for cloth (Chaudhuri (1978, p. 300-301)). The Directors set the auction price in London as the benchmark for the procurement price in India. But the benchmark was (i) determined as much as two years in advance, and (ii) only loosely related to local production costs. Hence, there was often an "acrimonious debate" (Hossain (1988, p. 73)) between managers in India and London over prices. ${ }^{31}$ The model shows that such a constraint would make it yet more difficult to strike the balance between agents and producers.

\footnotetext{
${ }^{30} \mathrm{~A}$ foreign exporter, like the EIC, is unlikely to know the distribution $F(\beta ; B)$ and hence the precise tradeoffs of raising and lowering $B$. The exporter could infer the results of its policies over time. A large literature studies learning in an uncertain environment, where there can be a tradeoff between actions that maximize current expected profits and those that increase a decision-maker's information. See, for example, Rothschild (1974) and Easley and Kiefer (1988).

${ }^{31}$ The cost of the Company's military adventures in India also generated pressure to offer low prices. It is possible that, at times, the price did not cover production costs; Mitra (1978, p. 109-118) provides some evidence. But even today it is difficult to accurately measure costs in a family enterprise. For instance, modern farm management surveys in India often find that if family labor inputs are valued at market prices economic profits can be negative (Bharadwaj (1974, p. 45)). In our study, the weaver received an interest-free advance, and, hence, some implicit compensation. Mitra's extensive discussion of the distress caused by the eventual closure of the EIC's factories in $19^{\text {th }}$ century suggests that weavers were making profits (p. 178-181, 198-200). Still, low prices remain a plausible factor in the Company's procurement problems.
} 
Throughout the textile operations, we see the EIC's struggle both to give agents enough power and to give weavers sufficient incentives. After 1757, and especially after 1765, the Company's agents had much power to enforce sales agreements. Contemporary observers describe this period as one where agents greatly exploited their positions. Bolts (1772) writes that agents undervalued cloth and would harass producers, often seizing output to prevent sales to other buyers: "the English Company's gomastah ... set his peons over the weavers to watch him and not infrequently to cut the piece from the loom when nearly finished." 32

The Company began to face procurement problems. In 1768, Governor Verelst wrote the Court of Directors in London of the decline:

Plenty has succeeded to famine and security has induced the natives to apply themselves again to labour and commerce, but the manufacturers are scarcely increased, the aurungs are not so well-peopled as they were twenty years before. ${ }^{33}$

His explanation exactly follows the lines of our model. In trying to prevent opportunism by the weaver, the Company had given too much power to the agent:

[I]t was thought expedient by the governor and council .... to make... advances to such manufacturers as would otherwise have lain idle. Contracts thus in part executed on one side, afforded a temptation to fraud on the other; and the workman, unless strictly watched, often resold his goods for their full price to a stranger. The gomastahs or agents of the Company were necessarily therefore entrusted with powers which they frequently abused to their own emolument; and an authority given to enforce a just performance of engagements became notwithstanding the vigilance of the higher servants, a source of new oppression (Verelst (1772, p. 85)).

Indeed, the Company's perception, in the language of our model, was that weaver's returns were too low, and their incentive constraints were violated. The Court of Directors in London wrote

\footnotetext{
${ }^{32}$ Quoted by Mitra (1978, p. 50). Jones (1918, p. 38) provides a very similar description.

${ }^{33}$ See Mitra (1978, p. 52). The Court of Directors in turn communicated its unhappiness to the EIC's management in Fort William in 1771, comparing the "once flourishing state of the commerce of Bengal with its present gradual decline (Mitra (1978, p. 54))." As Marshall (1976, p. 56) points out, such generalizations applied to Bengal's large and complex economy could be much too broad. However, the narrower claim that the gumashtas were abusing their powers and thereby hurting procurement is not in dispute.
} 
to the administration in Bengal in 1768: "We can ascribe your difficulties to nothing but the oppressed state the weavers have been in for some years which has occasioned many to fling up their looms (Mitra (1978, p. 50))." The policy B was too high, leading to greater probability of high realizations of agents' power. Procurement problems continued after the famine of 1770 , in which up to a third of the population died. In Santipore, for example, the price of cotton yarn rose by $25 \%$, and the EIC raised procurement prices. But agents were accused of expropriating the increase. The weavers complained that they were getting the same price as before because the gumashtas were undervaluing their products (Mitra (1978, p. 64)).

In 1773, the Company decided to change course. It instituted regulations to give producers "freedom of trade" and guard them against coercion. It also decided to try another means of procurement, the "Contract System."

The Company's new rules aimed to rein in the agents. Regulation IV of 1773 stated:

Whoever shall attempt, directly or indirectly, to force advances upon the weavers or make them enter into engagements against their will or in any way exercise an undue influence on them, shall be immediately suspended from the Company's service (Sinha $\left(1956\right.$, p. 170)). ${ }^{34}$

A 1775 legal notice reinforced this Act, warning gumashtas that weavers' freedom to deal with other buyers should not be restricted, and that they would be punished for violations (Hossain (1988, p. 112)). In terms of our model, such regulations reduce $B$. The producer's constraint is then violated less frequently, but the agent has less ability to enforce sales. And indeed now it was the agents' turn to complain that weavers were not delivering cloth (Wright (1961, p. 203), Mitra (1978, p. 55), Hossain (1988, p. 113)).

In response, another set of regulations was introduced in 1775, with the aim of increasing the agents' power. Agents were authorized to post a peon at a defaulting weaver's house to compel him to work. Weavers who secretly sold to other merchants while they were still in arrears to the

\footnotetext{
${ }^{34}$ If the gumashta had excessive power, he could not only violate the price terms, but force the transaction on the weaver in the first place. It is difficult to assess how common this phenomenon was, but weavers' petitions do complain about forced advances. Also, the fact that Company passed regulation forbidding this practice suggests that it did occur.
} 
EIC could be taken to court and punished (Mitra (1978, p. 56)).

In 1775 the EIC began its experiment with the Contract System, before returning exclusively to the Agency System in 1788 (Sinha (1956, p. 151), Mitra (1978, p. 134)). The EIC contracted with merchants who agreed to supply certain amounts and types of cloth at pre-specified prices. The Company gave advances to merchants, but merchants made their own deals with weavers. In the framework of our model, $w=0$, and the intermediary charges the exporter a price $P$ that ensures his own incentive and participation constraints are satisfied. Our model shows these differences by themselves would not have any impact on procurement, which ultimately depends on the intermediary's coercive power. If $B$ is the same for the merchant as for the Company's agent, the producer's constraint is violated with the same probability, and procurement problems remain. This is what happened, for reasons we explain next.

The Contract System involved another set of agency issues. As a company, the EIC could not effectively oversee the local allocation of contracts. Commercial Residents had shared in gumashtas' illegal profits under the Agency System and would not easily let go of them. Contracts were thus given to Commercial Residents themselves or to merchants in cahoots with them. ${ }^{35}$ These merchants acted virtually in the same manner as the company's agents, with the backing of the local company: "The contractors regarded themselves as the Company's representatives and the Company also let them freely use the power of coercion in the Company's name (Sinha (1956, p. 151))." Procurement problems persisted. For instance, in 1780 the contractor of Sonargang increased the number of quality gradations to twenty-four (!) thereby creating "so many openings to defraud the weavers" (Sinha (1956, p. 162)). Sinha's general assessment regarding procurement by the Company was that the two systems ultimately worked - or did not work - in exactly the same way: "After 1757 circumstances shaped in such a way that Agency or Contract did not matter much as far as Indians were concerned (1956, p. 21)."36

\footnotetext{
${ }^{35}$ The Company allowed its British employees to engage in private trade, but not between Europe and Asia (Hejeebu (2005), Cases-Arce and Hejeebu (2002)). Here the Company was using its own British employees as merchants to obtain goods for its European trade.

${ }^{36}$ Wright (1961, p. 204) quotes an official from Patna who, in 1777, complained about both weavers and merchants: "I do not mean by this representation of the conduct of the weaver to insinuate that there are no faults on the side of the contractor. Far from it, for I ever had the idea that in all the business in this country where it is necessary to employ intermediate agents there must be some misdemeanours and which, whilst matters remain on their present footing, it will be out of the power of the most strenuous exertions entirely to prevent."
} 
Reports of weaver opportunism persisted, and the EIC responded further. Proceedings of the Board of Trade in 1783 told of weavers using the Company's interest-free advances to buy lowerquality threads and selling to private merchants. ${ }^{37}$ One way to hide these sales was to weave in another house. A slew of regulations in the 1780's then aimed to punish buyers and sellers of cloth under contract to the EIC. ${ }^{38}$ Regulations passed in 1787 and 1789 set punishments and fines for weavers failing to meet delivery schedules.

With this backing, EIC intermediaries - agents and merchants - continued to siphon off rents. And we see protests from weavers. In 1787 weavers of Narainpur and Savar complained of fraud, and weavers of Sonargaon, Titabadi, and Bajitpur objected to a "strong and artful combination of gomastahs, the inferior arang servants and the principle [sic] weavers of every district (quoted by Hossain 1988, p. 169)." In 1794 the weavers of Dacca wrote that "Cloths of 2100 threads were taken as 2000 threads letter C and D..." as the Commercial Resident colluded with the appraisers and gumashtas to undervalue their cloth (Mitra 1978, p. 81 ). ${ }^{39}$ Board of Trade documents from 1815 and 1818 - near the end of the textile venture - show continued evidence of opportunistic behavior by gumashtas (Ghoshal (1966, p. 11)).

If the Agency System did not work well, why did not the Company adopt an alternative structure, as suggested by today's industrial organization theory? Why did not the EIC establish a vertically integrated firm, where it owned the fixed capital (looms), bought the inputs (yarn), and hired producers (weavers) as employees? Why did not repeated interaction between the EIC's agents and the weavers overcome the enforcement problems?

Vertical integration would have been difficult for several reasons. The weavers were mostly

\footnotetext{
${ }^{37}$ See Mitra (1978, p. 66). In a similar vein, in 1786 the Resident of Malda complained of "the unfair practice of selling clandestinely to individuals cloths manufactured for the Company" (Hossain (1988, p. 118)).

${ }^{38}$ The Regulation of April 1782 announced that "the purchasers of the said cloths, apparently knowing them to be the property of the Company, by the secret and clandestine way manner which they take to procure them or by the notoriety of the weavers being in the Company's employ who offers to dispose of them, on proof of the fact, shall be liable to punishment by the Adaulat [court] according to the nature of their offence and the cloths so purchased shall be confiscated" (Mitra (1978, Appendix IA, p. 222)). Regulation XIV in 1786 addressed a loophole: "Whereas it has been alleged that the Company's weavers cannot be distinguished from others it is hereby ordered that a list or register of the weavers employed by the Company in every pergannah be stuck up by the Commercial Agent..." Regulation XI warned weavers not to sell cloth "either by himself, any of his family or by any agent, to any other merchants or dealers whatever, whilst he is deficient in his deliveries..." (Sinha (1956, p. 153)).

${ }^{39}$ Similar complaints against gumashtas are included in petitions from 1795 and 1801, reproduced in Mitra (1978, p. 253-235).
} 
part-time agriculturists and scattered over a huge area. ${ }^{40}$ It would have been quite a challenge to have weavers leave their homes and farms to work in a centralized location. In addition, vertically integrated structures involve a different set of agency problems. Weavers and supervisors would all have to be monitored or given incentive contracts in order to perform their work well. ${ }^{41}$ In the Agency System, the weavers were residual claimants. It is possible that decentralization, with its faults, ultimately provides better incentives than vertical integration.

Theory and realities on the ground point to several reasons why repeated interaction was unlikely to lead to cooperation in our setting. First, discount rates were high: ${ }^{42}$ Colonial Bengal was a society in flux. Weavers and agents likely did not know how long their relationships would continue. There were "shocks" of various kinds: a major political transition; the massive famine in 1770 which may have killed as much as a third of the population; frequent changes of EIC personnel $;^{43}$ numerous policy changes, which we have documented; and law and order problems. ${ }^{44}$ In such an environment it may have been rational for all parties to maximize short-term profits. Second, active markets and the presence of outside options makes cooperative relations more difficult to sustain. ${ }^{45}$ To eliminate this factor, buyers would have to cooperate with each other, and producers as well. E.g., producers share information and collectively boycott any buyer that behaves opportunistically. And buyers collude. The EIC and its rivals could have divided the markets geographically and promised not to poach each other's weavers. Indeed, the Dutch Company did suggest this. The EIC did not agree - after gaining political hegemony it wanted to dominate the trade, not share it. As for weavers, they were too geographically dispersed to form a successful cooperative. Moreover, they likely feared prosecution by the EIC and persecution by

\footnotetext{
${ }^{40}$ K.N.Chaudhuri (1978 p. 241) writes: "There were few villages and towns in Coromandel and Bengal, as Orme aptly observed, where at least a few families of weavers could not be found." He attributes this regional dispersion in Bengal (as compared to, say, Western India) to the availability of easy transport via inland waterways.

${ }^{41}$ Mitra (1978, p. 41) reports that the weavers in the royal workshops were under "incessant inspection."

${ }^{42}$ Even when players have low discount rates, it is important to remember that the Folk Theorem indicates that any outcome is possible. A cooperative equilibrium where agents and producers fulfill contract terms would be as likely as an equilibrium where they act opportunistically.

${ }^{43}$ Life expectancy among the EIC's civil servants was low. Marshall (1976, p. 219) reports that $59 \%$ of those entering in the period 1756 to 1766 died in India, compared to "only" 44\% entering in the period 1767-1775. Hejeebu (2005) reports that the median length of service was 9 years. Death was the reason for $75 \%$ of departures in the first five years and $66 \%$ of departures in the second five years.

${ }^{44}$ The Company had weakened the authority of the zamindars (landlords), and its own police force was ineffective into the early nineteenth century. Crime and 'dacoity' (banditry) were rampant. See Marshall (1987, p. 130).

${ }^{45}$ See Kranton (1996) and Baker, Gibbons, and Murphy (2002).
} 
social superiors affiliated with EIC upper management (Hossain (1988, p. 177)).

Thus, the contractual problems continued to the very end. It is conceivable that, over time, as the EIC's administrative capacity improved, it would have streamlined the textile procurement process. But we will never know. In the early 1800's, as the industrial revolution took off, cloth manufactured in England eliminated the EIC's Bengali cotton textile trade. To see a "mature" EIC in operation we will have to study the Opium Monopoly.

\section{B. The Opium Monopoly}

In the opium venture, we argue the EIC's administration and later that of the Crown were better able to strike the balance between agents' power and producers' incentives. As an official and largely enforceable monopsony, the EIC limited producers' opportunities for outside sales. At the same time, the EIC invested in an institutional apparatus to monitor its own agents. Finally, the EIC was also able to set the procurement price largely without constraint. Our model indicates that these features, in combination, lead to high procurement and high exporter profits: $m$ is low, the exporter can set $P$, and the exporter can precisely target agents' power $\beta$ with its policies $B$.

After the Battle of Plassey in 1757, EIC officials saw another money-making opportunity: the opium trade centered around Patna (Bihar). After several decades of policy experimentation, in 1797 the Company set up an Agency System for monopoly procurement of opium in Patna and in another procurement center, Benares. ${ }^{46}$ Under the Opium Agency private cultivation of poppy and sale of opium were banned. Via its agents, the Company gave capital advances to farmers who were required to grow poppy on a specified area, harvest the juice, prepare raw opium, and deliver it to agents for payment minus advances and deductions for quality defects. Large amounts of opium were procured, most of which was auctioned in Calcutta to private traders who sold it in China. The Opium Agency earned enormous profits, which constituted as much as $17 \%$ of government revenues in 1858-59. ${ }^{47}$ On various occasions the Agency, like a textbook monopolist,

\footnotetext{
${ }^{46}$ British opium trade went through four phases: (i) After 1757, private participation by Company officials, whose control of the market grew with EIC domination, (ii) After 1765, formal declaration of a monopoly controlled privately by these officials, (iii) From 1773, a monopoly run by and on behalf of the Company, using the Contract System, and (iv) From 1797 onwards, a Company monopoly using the Agency System. The Contract System was abandoned following complaints that now sound familiar: corruption in awarding of contracts, abuse of peasants by contractors, and adulteration of opium.

${ }^{47}$ In 1775 Warren Hastings decided that opium profits would be governmental revenue rather than private com-
} 
increased revenues by adjusting its supply according to demand, all the while maintaining the high quality for which its opium was famous. ${ }^{48}$ The Opium Agency remained in place for more than a century. ${ }^{49}$ Why was it so successful?

The Opium Agency, we argue, better addressed the procurement problems that had plagued the textile trade. Especially in the early years, we see many complaints of opportunism by farmers and agents. Agents often cheated farmers. Peasants in Saran (1811) and Shahabad (1812) submitted petitions complaining that gumashtas were under-weighing their raw opium (Singh (1980, p. 168)). Chowdhury (1964, p. 55) describes the findings of an 1820 report that "pointed out that the peasants hardly got anything from poppy, almost the whole amount having been misappropriated by zillahdars [intermediaries]." In 1832 the Deputy Opium Agent of Fatehpur wrote to the Board of Customs, Salt, and Opium: "It appears to me that two principal circumstances form the chief obstacles to an extensive poppy cultivation in this district, viz., the inadequate price the cultivators receive for their opium and the oppression to which they are subjected from the gomastahs (Singh (1980, p. 249))." There were also reports that peasants were forced to grow poppy, especially when the Agency was trying to quickly increase output (Chowdhury (1964, p. 50), Owen (1934, p. 108-109)). We also see familiar complaints about producers' behavior. They cheated on quality; Trocki (1999, p. 62) writes that adulteration of raw opium with sugar, poppy rubbish, earth, or flour was a persistent problem. Farmers also tried to sell to smugglers, at least in part because the prices they received from the Agency were too low: The head of the Opium Agency in Bihar claimed, in 1817, that because its price was low "more than half of those who take advances receive them with a view of smuggling a certain portion of the produce (quoted by Chowdhury (1964, p. 28))."

We argue the Opium Agency was ultimately able to manage these enforcement problems because, first, it had market power, and second (relatedly), it established a system to monitor

\footnotetext{
mercial profits for the EIC (Richards (1981, p. 67)).

${ }^{48}$ In 1831, facing competition from opium produced in the western Indian region of Malwa, the EIC decided to flood the market. Within five years it had tripled the output compared to the previous decade. In the early 1850's when prices were beginning to fall, it maintained revenues by reducing production from 50,000 chests to 21,000 chests (Owen (1934, p.108, 183)).

${ }^{49}$ The Bihar agency was closed in 1910. The Undersecretary of State for India announced the end of the opium trade to China in 1913 (Owen (1934, p. 348)).
} 
its agents. In our model, market power has several implications. The value, $\bar{v}$, of obtaining the product would be large. Opium was a lucrative commodity: It sold at auction for amounts well above procurement prices. For instance in 1820-21 in Bihar, peasants received 3 sicca rupees per seer and the auction price in Calcutta was 54 sicca rupees (Singh (1980, p. 173)). A monopsony also implies a small $m$ : Regulation VI of 1799 declared contraband trade in opium punishable by imprisonment (Singh (1980, p. 172)). Though smuggling was not completely eradicated, the situation was quite different for opium than for textiles, where in some locations only a third of the weavers worked for the Company (Mitra (1978, p. 165-166)).

While producers' lack of outside options could give agents greater opportunities for hold-up, it appears that, precisely because opium was so lucrative, the Agency invested in systems of authority and supervision. Richards (1981, p. 70) argues that by the Crown period a "systematic bureaucratic structure" had evolved. ${ }^{50}$ Each Opium Agency (Patna and Benares) was managed by a British officer and had numerous sub-agencies (16 for Benares and 11 for Patna), which were also manned by British officials (the Sub-Deputy Opium Agent and his assistant). Each sub-agency was, in turn, linked to 3-4 kothis or sub-divisional offices, which were handled by an Indian officer titled gumashta, or agent. The gumashta had a support staff of twenty-five clerks, soldiers, and "opium patrol officers." The gumashta dealt with a village intermediary, often the village headman. At the start of the Opium Year (September 1), the gumashta and the Sub-Deputy Opium Agent negotiated with the village intermediary who drew up a list of peasants who would grow opium. A license was issued in each name. When signed acceptance was returned to the Agency's representatives, farmers received interest free-advances, usually in 2-4 installments. Around April the village intermediary notified the peasant to appear at the $k o t h i$ where the opium was weighed, graded, and examined for adulteration in the presence of the British Assistant Sub-Deputy or another officer (Richards (1981, p. 76)). By the 1860's chemical tests were being used for adulteration, which would have further reduced the gumashta's discretion (Trocki $\left(1999\right.$, p. 98)). ${ }^{51}$

\footnotetext{
${ }^{50}$ As mentioned earlier, in 1858 the British Crown dispensed with the Company and took over administration of India.

${ }^{51}$ Historians widely comment on another feature of the Opium Agency: the high price of opium did not translate into substantial gains for farmers. Even the most favorable assessment (Richards 1981, p.79) finds that farmers'
} 
Improvement in the Company's (and subsequently the Crown's) administration in India also played an important role in checking opportunism: the management of the Opium Agencies was significantly less corrupt than its counterpart in the textile venture. The transition is dated from the mid 1780's with a shift from "affluence to integrity as a measure of value" (Misra (1977, p. 53)). During Cornwallis' tenure as Governor-General (1786-1793), eliminating corruption was a priority. Salaries were increased and private trade by Company servants was banned. The nineteenth century brought greater improvement. Company officers spent three years at a college in Haileybury before coming to India; influence peddling (in London) for appointment became less salient, and in 1853 competitive entrance exams were introduced. This management had much discretion over procurement prices. Chowdhury (1984, p. 314) provides one example: in the 1850's, following a decline in cultivation, the Agency increased its procurement price by $42 \%{ }^{52}$

With the development of an effective institutional apparatus and professional staff, it appears that opium procurement became completely routinized. John Rivett-Carnac, of the Indian Civil Service, ran the Benares Opium Agency for twenty years from 1875-1894 and wrote his successorto-be that, while the job was not very challenging, it "offered this advantage, that here a man might towards the close of his service make a comfortable and quiet haven for later years in India (Rivett-Carnac (1910, p. 303-304))."

\section{Land Taxes}

The history of land tax collection in Bengal lends support to our analysis of the EIC's procurement ventures. Land taxes were the largest source of revenue for the East India Company. In collecting these taxes, the Company relied on intermediaries, and we see familiar tradeoffs in setting their level of coercive power.

In 1793 the Company established the famous "Permanent Settlement," a radically new way to collect land taxes. The Company granted land ownership in return for yearly taxes, whose

incomes stabilized, rather than increased. Thus, it appears that the Opium Agencies, because they could better regulate the coercive power of their staff, were able to procure consistently even as they extracted a lion's share of the surplus.

${ }^{52}$ We see further evidence of the Agency's financial flexibility in its policy, at times, of interest-free loans for poppy cultivators to dig wells (Owen (1934, p.107), Richards (1981, p. 75)). 
nominal amount would never change. The new owners were zamindars, who had largely collected taxes on behalf of pre-colonial rulers and whom the EIC had used as intermediaries since 1777. Under the Permanent Settlement, the zamindar owned the land, and the land would "positively and invariably" 53 be sold if the zamindar did not pay the tax. This system simplified the complex pre-existing property rights and tax collection relationships with which the Company had grappled since its arrival (Sinha (1968), Guha (1963)). It was also grounded, at least somewhat, in economic logic: Cornwallis believed the zamindar would have an incentive to develop his property since, with secure ownership and a fixed tax, he would earn any gains in productivity. ${ }^{54}$

To pay his taxes a zamindar had to collect rents from tenants, and we see that the EIC struggled to find a balance between the two parties. The Company specified the zamindar's coercive powers in a series of Regulations, and disputes were adjudicated in District Courts. ${ }^{55}$ To limit the burden on these courts, and "for the convenience of parties residing at a distance from the seat of justice (Firminger (1917, p. 57)," Indian judicial officers known as "Native Commissioners" were authorized to adjudicate suits for small sums.

The Proclamation of 1793 which established the Permanent Settlement seemed to favor tenants. It eliminated the zamindar's traditional right to jail or physically punish a defaulting tenant. The zamindar could "distrain" (seize) the tenant's personal property - crops, cattle etc., but this distraint had to be withdrawn if the tenant provided security and contested the claim in District Court. The tenant's seed grain, implements, and cattle physically connected to the plough could not be attached if there were other assets available (Banerjee and Ghosh (1977, p.xiv)).

These regulations, however, apparently gave too little power to zamindars. They complained that it was difficult to collect rents. Moreover, they charged that larger tenants were tying them up in court, while the government promptly sold their land when they failed to pay the taxes.

In response, in 1795 the Company eased the restrictions on the zamindar's power. The zamindar no longer had to withdraw the distraint of property when challenged in court (Sinha

\footnotetext{
${ }^{53}$ See Article VI of the Proclamation of March 22, 1793, Harrington (1814-15, Volume II, p. 198).

${ }^{54}$ See Governer-General's Minute September 18, 1789, in Firminger (1917, Vol. II, p. 511). Of course, fixing the tax in nominal terms is contrary to current economic thinking.

${ }^{55}$ See our overview of the EIC's administrative history above. To protect the property rights of zamindars, revenue officials ("collectors") could no longer serve as judges.
} 
(1968 p. 171)). After giving the tenant three days' notice, the zamindar could approach the district judge to jail the tenant after a summary investigation (Islam (1979, p. 54)).

Even these measures were considered inadequate, and in 1799 the to-be-notorious Regulation VII was passed. The zamindar could now sell the distrained assets while waiting for a judicial decision (Islam (1979, p.64)). If the zamindar feared that the tenant might abscond, the zamindar could appeal to the Native Commissioner who, even without investigating the facts, could arrest the tenant and bring him before a district court judge. Most importantly, the Regulation specifically allowed the zamindar, on his own authority, to coerce a tenant:

$\ldots[\mathrm{N}] \mathrm{o}$ part of the existing regulation was meant to deprive the zamindars and other landholders of the power of summoning, and if necessary of compelling the attendance of their tenants, for the adjustments of their rents, or for any other just purpose (Chatterjee (1864, p. 89)).

Now, it appears, the zamindars had too much power - a "blank cheque" - according to some historians (Sinha (1968, p. 171)). British revenue officials reported that zamindars were abusing their powers to extract exorbitant rents. Tenants deserted in some areas (ChowdhuryZilly (1982)). The revenue officials noted these complaints but also worried that reforms might swing the pendulum too much in the other direction:

....Great caution therefore must be observed not to relax too much in favor of the ryots [farmers], lest we should run into the other extreme, and afford them, by the abuse of the protection which the law affords, the means of withholding the just payment of their rents (Islam (1979, p. 69)).

New regulations were ultimately passed in 1812, this time to protect the tenant (but see below). The defaulter's assets could no longer be sold without court permission. (Islam (1979, p. 70)). The zamindar had to withdraw the attachment if it was contested in court, with the tenant providing security (Harrington (1817, Vol. III, p. 529)). The cattle connected to the plough, seed-grain, and implements were now unconditionally exempt from seizure (Chatterjee (1864, p. $95))$. 
In the regulation of zamindar and tenant, we see parallels to the textile and opium ventures. We see much legal back-and-forth reminiscent of the textile agents and weavers. ${ }^{56}$ From the second half of the $19^{\text {th }}$ century, the emphasis shifted to providing security of tenure and rent protection for tenants. This increased willingness to intervene and regulate reflected the regime's growing administrative capacity described earlier in the context of opium procurement. ${ }^{57}$ The Zamindari system was abolished shortly after colonial rule ended in $1947 .^{58}$

\section{Present-Day Example: Contract Farming}

Agency systems and similar arrangements abound in today's developing world. Multinationals and parastatals often use "contract farming" to procure commodities for export, such as coffee, cotton, and fruit. ${ }^{59}$ Buyers advance credit or inputs to the grower. Growers are then supposed to deliver the output and receive a quality-contingent final price, minus any debt repayment. Buyers sometimes also provide technical assistance. Enforcement problems appear to be widespread: producers default on advances often by engaging in outside sales, and buyers renege on price commitments often by manipulating quality criteria.

A variant, indeed a simplification, of our model captures the essence of these problems. An important distinction between the EIC and today's buyers is that the latter do not control state power. When multinationals and parastatals cannot regulate high levels of coercive power like the EIC, in our framework $B$ would be low. The probability of procurement then depends on the parameter $m$, which captures the extent of market competition. We could model the level of competition as random, like we did the level of agents' power. When $m$ is high, the producers

\footnotetext{
${ }^{56}$ In another parallel, financial imperatives led to a high land tax (just as the EIC was likely constrained in its textile prices). High taxes left little surplus for zamindar and tenant to share, with defaults on either side. Islam (1979, p. 25) calls the tax fixed in 1793 "unbearably high in the context of the conditions of the zamindars at that time." Even Marshall (1987, p. 144), who takes a more moderate view, suggests that the land tax for Bengal was roughly $20 \%$ higher in real terms in 1793 than in 1757.

${ }^{57}$ When the Permanent Settlement was introduced, the Company was aware of customary norms protecting tenants from arbitrary eviction and rent increases. It introduced a law requiring landlords to provide ten-year leases, specifying rents. This rule was rarely enforced and widely opposed, and was rescinded in 1812, officially giving the zamindar a free hand in his dealings with tenants. In essence, the Company knew it lacked the capacity to regulate landlord-tenant relations, and merely reserved the right to intervene in the future. It did so in the Bengal Rent Act of 1859 and the Bengal Tenancy Act of 1885.

${ }^{58}$ However, its effects appear to have persisted post-independence (Banerjee and Iyer (2005)).

${ }^{59} \mathrm{It}$ is argued that in some instances, a concern about nationalization and union activity are behind preferences for contract farming rather than plantation farming.
} 
will be tempted by outside sale opportunities, and the buyer who initially advanced the capital will incur losses. On the other hand, when $m$ is low the buyer will be able to pay a very low price and hold-up the grower. ${ }^{60}$

A good example of the problem in competitive environments (high $m$ ) is Jaffee's (1994) account of the travails of Kenya Horticultural Exports (KHE), which exported fresh produce in the 1980's. KHE's contract farming scheme fell apart in 1985: prices increased because of a drought, and farmers sold their crops to other exporters at higher prices. The KHE was unable to recover many input loans. Attempts to rescue the scheme were unsuccessful, as more than a dozen exporters were operating in the area, ready to poach on KHE's efforts. Jaffee (p. 125) reports that eventually "the lesson learned by KHE managers from this experience is that in the competitive trading environment that characterizes Kenya's fresh produce trade, contract farming arrangements are not sustainable." In a similar vein, Brambilla and Porto (2005) report that in Zambia, after agricultural liberalization in the 1990's, contract farming in cotton faced increasing problems of default following entry by new firms.

On the other hand, lack of competition (low $m$ ) allows buyers to behave opportunistically. Hightower (1975, p. 17) reports that Del Monte paid American asparagus growers almost nothing (0.0005 cents per pound) for rejected produce. The company alone had the right to judge quality, and, with no alternative, farmers had to accept these prices. Clapp (1994, p. 94) describes a case in Guatemala when, faced with a surplus of production, ALCOSA, a subsidiary of Birdseye, exploited an escape clause which the illiterate farmers were unaware of, and unilaterally suspended purchase in a village named Chimachoy. Two-thirds of the farmers found no other buyer and onethird did not even bother to harvest the crop.

\section{Conclusion}

The message of this paper thus far may seem excessively bleak to some readers. In only one case we have studied, the Opium Monopoly, did the exporter achieve the balance between its

\footnotetext{
${ }^{60}$ In his analysis of contract farming in Thailand Siamwalla (1978) provides an intuition similar to ours, using the term "shifting costs:" when costs are low, markets are competitive and buyers will be reluctant to advance capital; when costs are high, markets are monopsonistic and buyers will capture most of the surplus.
} 
representatives' power and producers' incentives. Given the ubiquity of arrangements like the Agency System, surely there must be more instances where opportunistic behavior is checked. We conclude with two examples of successful ventures, each illustrating a class of solutions to the problems we have highlighted.

Institutions in manufacturing towns in Gujarat (in Western India) in the late nineteenth and early twentieth centuries facilitated cooperative relations between buyers and producers. Consider the following description of Ahmedabad provided by Mehta (1984), using late $19^{\text {th }}$ century sources. ${ }^{61}$ Producers in a given occupation (weavers, potters, etc.) lived and worked together in distinct neighborhoods; merchants also lived close to each other, in a different part of the city. Each occupational group had its own association. Caste and religious ties facilitated cooperation. Members of each group agreed to act collectively to punish transgressions by their own members and to retaliate against members of other groups when necessary. Merchants often advanced either raw materials or cash to artisans. But they could not "exploit" the artisans "beyond a point" because the artisans "could always act through the powerful mechanisms of the Panch [their association]." Merchant associations were also vigorous in defending their members' interests. ${ }^{62,63}$ In such a setting, hold-up problems may be infrequent because of fear of collective retaliation, and procurement should occur smoothly.

Closed communities provide another way to counter opportunism, with institutions for dispute resolution, mechanisms for social sanction, and a strong shared sense of identity. Tirthankar Roy's (1997) description of the Sourashtras in the South Indian town of Madurai is one example. The Sourashtras are a successful and close-knit migrant community, quite aware of their distinct origins. Their traditional occupation is the production and sale of textiles, and the community includes both weavers and merchants. There is a norm of transacting within-group: most

\footnotetext{
${ }^{61}$ Hopkins (1902) and Gazetteers produced by the colonial government describe a similar social structure in towns like Bharuch and Surat.

${ }^{62}$ Haynes (1996, p. 306), studying the jari (gold thread) industry in the Gujarati town of Surat in the early twentieth century describes how artisan families formed long-term relationships with merchants and could "change patrons only when a new bidder for their services offered to pay their old debts."

${ }^{63}$ An interesting example of cooperation among merchants in the silk industry comes from another region. According to the Report of the Bihar and Orissa Provincial Banking Enquiry Committee, 1929-30 (p. 92) the mahajans (moneylenders), who had given advances to weavers, had "a sort of trade combination to protect their unsecured debts. No weaver can go to another mahajan without a certificate of discharge from his old mahajan."
} 
Sourashtra weaver families work in "stable putting-out contracts with Sourashtra merchants" (p. 44). In Roy's study, which spans the late nineteenth to the late twentieth centuries, there is no mention at all of the types of opportunistic behavior we have examined. This absence of contract breach is consistent with his emphasis on the cohesion of the Sourashtras. Roy quotes an early $20^{\text {th }}$ century monograph that holds the Sourashtras were "very keen to stick to truth in their dealings." He concludes that "common identity ensured that trust was not betrayed" and that agency costs were thereby avoided (p. 462). Of course, there is now a literature in economics that explains how repeated interactions within a closed community can facilitate cooperation and contract enforcement. ${ }^{64}$

In this paper we have studied the microeconomics of export procurement. We have examined the problems of contracting between exporters and local producers - problems that must be overcome for globalization to fulfill its promise of raising incomes of the world's poor. A wellfunctioning legal apparatus could enforce contracts and check opportunism on both sides. Public investment in such an apparatus would be socially efficient if the future gains from trade are high. In the absence of formal contract enforcement, our model indicates the market structure and a balance of bargaining power are critical to the success of procurement operations. Export efforts are then likely to be most successful when (1) production and export both take place within the same community that mobilizes the various forces that sustain cooperative behavior, (2) producers and exporters work as collectives to reduce outside sales and punish opportunism on both sides, and (3) a monopsony invests in its own enforcement apparatus that checks its own opportunistic behavior.

\footnotetext{
${ }^{64}$ For prominent examples see Greif (1993) and Clay (1997). See Kandori (1992) for the general theory of repeated games and community enforcement.
} 


\section{References}

Baker, G., Gibbons, R., and Murphy, K. 2002. "Relational Contracts and the Theory of the Firm," Quarterly Journal of Economics, Vol. 117 (1), p. 39-84.

Banerjee, A. and Duflo, E. 2000. "Reputation Effects and the Limits of Contracting: A Study of the Indian Software Industry," Quarterly Journal of Economics, Vol. 115 (3), p. 989-1017.

Banerjee, A. and Iyer, L. 2005. "History, Institutions, and Economic Performance: The Legacy of Colonial Land Tenure Systems in India," American Economic Review Vol. 95 (4), p. 1190-1213.

Banerjee A.C. and Ghosh, B.K. 1977. Introduction to Bengal Ryots: Their Rights and Liabilities: Being an Elementary Treatise on the Law of Landlord and Tenant by S.S. Chatterjee, i-xxxvii. Columbia, Mo: South Asia Books.

Bardhan, P. 1980. "Interlocking Factor Markets and Agrarian Development: A Review of the Issues," Oxford Economic Papers, 32: 82-95.

Bardhan, P. 1989. "A Note on Interlinked Rural Economic Arrangements," in P. Bardhan ed. The Economic Theory of Agrarian Institutions. Oxford: Clarendon Press.

Bharadwaj, K. 1974. Production Conditions in Indian Agriculture, London: Cambridge University Press.

Biggs, T., Raturi, M., and Srivastava, P. 2002. "Ethnic Networks and Access to Credit: Evidence from the Manufacturing Sector in Kenya," Journal of Economic Behavior and Organization, 49: 473-86.

Bihar and Orissa Provincial Banking Enquiry Committee. 1930. Report of the Bihar and Orissa Provincial Banking Enquiry Committee, 1929-30. Calcutta: Government of India Central Publication Branch. 
Bolts, W. 1772. Consideration on Indian Affairs. London.

Bose, S. 1993. Peasant Labour and Colonial Capital: Rural Bengal Since 1770. Cambridge: Cambridge University Press.

Brambilla, I. and Porto, G. 2005. "Farm Productivity and Market Structure: Evidence from Cotton Reforms in Zambia," Mimeo, Yale University.

Carlos, A. M. and Nicholas, S. 1990. "Agency Problems in the Early Chartered Companies: The Case of Hudson's Bay Company," Journal of Economic History, Vol. 50 (4), p. 853-875.

Casas Arce, P., and Hejeebu, S. 2002. "Job Design and the Benefits of Private Trade," Mimeo, Harvard University.

Chatterjee, S.S. 1864. Bengal Ryots, their Rights and Liabilities: Being an Elementary Treatise on the Law of Landlord and Tenant. Repr., Columbia, Missouri: South Asia Books, 1977.

Chaudhuri, K. N. 1978. The Trading World of Asia and the English East India Company, 1660-1760. Cambridge: Cambridge University Press.

Chaudhury, S. 1995. From Prosperity to Decline: Eighteenth Century Bengal. Delhi: Manohar.

Chowdhury, B.B. 1964. Growth of Commercial Agriculture in Bengal (175\%-1900), Vol. 1. Calcutta: Indian Studies.

Chowdhury, B.B. 1984. "Eastern India II," in D. Kumar ed. The Cambridge Economic History of India, Volume II: 1757-1970. Delhi: Orient Longman.

Chowdhury-Zilly, A.N. 1982. The Vagrant Peasant: Agrarian Distress and Desertion in Bengal 1770 to 1830. Wiesbaden: Franz Steiner Verlag.

Clapp, R.A. 1994. "The Moral Economy of the Contract," in Peter D. Little and Michael J. Watts eds. Living Under Contract: Contract Farming and Agrarian Transformation in SubSaharan Africa, Madison, WI: University of Wisconsin Press. 
Clay, K. 1997. "Trade without Law: Private-Order Institutions in Mexican California," Journal of Law, Economics and Organization, Vol. 13 (1), p. 202-31.

Easley, D. and Kiefer, N. 1988. "Controling a Stochastic Process with Unknown Parameters," Econometrica, Vol. 56, No. 5 (September 1988), p. 1045-1064.

Edlin, A. and Hermalin, B. 2000. "Contract Renegotiation and Options in Agency," Journal of Law, Economics, and Organization, Vol. 16, p. 395-423.

Fafchamps, M. 1997. "Trade Credit in Zimbabwean Manufacturing," World Development, 25, $795-815$

Firminger, W. K. 1917. ed. The Fifth Report from the Select Committee of the House of Commons on the Affairs of the East India Company, Volumes I, II. Repr., New York: August M. Kelley, 1969.

Ghoshal, H.R. 1966. Economic Transition in the Bengal Presidency (1793-1833). Calcutta: Firma K.L. Mukhopadhyay.

Greif, A. 1993. "Contract Enforceability and Economic Institutions in Early Trade: The Maghribi Traders' Coalition," American Economic Review, Vol. 83, No. 3 (June), p. 525-548.

Griffiths, P. 1952. The British Impact on India. London: Macdonald and Co.

Grossman, S. and Hart, O. 1986. "The Costs and Benefits of Ownership: A Theory of Vertical and Lateral Integration," Journal of Political Economy 94, p. 691-719.

Guha, R. 1963. A Rule for Property in Bengal: An Essay on the Idea of the Permanent Settlement. Paris: Moulton and Co.

Harrington, J.H. 1814-15. An Elementary Analysis of the Laws and Regulations Enacted by the Governor General in Council, at Fort William in Bengal, for the Civil Government of the British Territories Under that Presidency, Volume II. Calcutta: The Honorable Company's Press. 
Harrington, J.H. 1817. An Elementary Analysis of the Laws and Regulations Enacted by the Governor General in Council, at Fort William in Bengal, for the Civil Government of the British Territories Under that Presidency, Volume III. Calcutta: The Honorable Company's Press.

Hart, O. and Moore, J. 1990. "Property Rights and the Nature of the Firm," The Journal of Political Economy, Vol. 98, No. 6 (December), p. 1119-1158.

Haynes, D. 1996. "The Dynamics of Continuity in Indian Domestic Industry: Jari Manufacture in Surat, 1900-47," in T. Roy ed. Cloth and Commerce: Textiles in Colonial India, AltaMira Press: New Delhi.

Hejeebu, S. 2005. "Contract Enforcement in the English East India Company," Journal of Economic History, 65, No. 2, p. 496-523.

Hightower, J. 1975. Eat Your Heart Out: Food Profiteering in America. New York: Crown Publishers.

Hopkins, E. W. 1902. "Ancient and Modern Hindu Guilds," in India: Old and New. New York: Charles Scribner's Sons.

Hossain, H. 1988. The Company Weavers of Bengal. Delhi: Oxford University Press.

Islam, S. 1979. The Permanent Settlement in Bengal: A Study of its Operation 1790-1819. Dacca: Bangla Academy.

Jaffee, S.M. 1994. "Contract Farming in the Shadow of Competitive Markets: The Experience of Kenyan Horticulture," in Peter D. Little and Michael J. Watts eds. Living Under Contract: Contract Farming and Agrarian Transformation in Sub-Saharan Africa, Madison, WI: University of Wisconsin Press.

Jones, M. 1918. Warren Hastings in Bengal, 1772-1774. Oxford: Clarendon Press.

Kandori, M. 1992. "Social Norms and Community Enforcement," Review of Economic Studies, Vol. 59 (1), p. 63-80. 
Kranton, R. 1996. "Reciprocal Exchange: A Self-Sustaining System," American Economic Review, Vol. 86 (4) September, p. 830-851.

Marshall, P.J. 1976. East Indian Fortunes: The British in Bengal in the Eighteenth Century. Oxford at the Clarendon Press.

Marshall, P. J. 1987. The New Cambridge Economic History of India, Vol. II, 1: Bengal: The British Bridgehead. Cambridge: Cambridge University Press.

McMillian, J. and Woodruff, C. 1999. "Interfirm Relationships and Informal Credit in Vietnam," Quarterly Journal of Economics, Vol. 114 (4), p. 1285-1320.

Mehta, S. 1984. "The Mahajans and Business Communities of Ahmedabad," in D. Tripathi ed. Business Communities of India: A Historical Perspective. New Delhi: Manohar.

Misra, B.B. 1959. The Central Administration of the East India Company, 17r3-1834. Manchester, England: Manchester University Press.

Misra, B.B. 1961. The Judicial Administration of the English East India Company in Bengal 1765-1782. Delhi: Motilal Banarsidass.

Misra, B. B. 1977. The Bureaucracy in India: An Historical Analysis of Development up to 1947. Delhi: Oxford University Press.

Mitra, D. B. 1978. The Cotton Weavers of Bengal, 1757-1833. Calcutta: Firma Mukhopadhyay.

North, D. 1990. Institutions, Institutional Change, and Economic Performance. Cambridge: Cambridge University Press.

Owen, D. E. 1934. British Opium Policy in India and China. New Haven: Yale University Press.

Prakash, O. 1976. "Bullion for Goods: International Trade and the Economy of Early Eighteenth Century Bengal," Indian Economic and Social History Review 13, p. 159-187. 
Rauch, J. and Watson, J. 2003. "Starting Small in an Unfamiliar Environment," International Journal of Industrial Organization, Vol. 21, p. 1021-1042.

Richards, J.F. 1981. "The Indian Empire and the Peasant Production of Opium in the Nineteenth Century," Modern Asian Studies, Vol. 15, (1), p.59-82.

Rivett-Carnac, J.H. 1910. Many Memories of Life in India, at Home and Abroad. Repr., www.elibron.com: Elibron Classics, 2005.

Robb, P. 1997. Ancient Rights and Future Comfort: Bihar, the Bengal Tenancy Act of 1885 and British Rule in India. Richmond, Great Britain: Curzon Press.

Rothschild, M. 1974. "A Two-Armed Bandit Theory of Market Pricing," Journal of Economic Theory, 9 (2), (October 1974), p. 185-202.

Roy, T. 1997. "Capitalism and Community: A Study of the Madurai Sourashtras," Indian Economic and Social History Review, 34 (4), p. 437-463.

Trocki, Carl A. 1999. Opium, Empire, and the Global Political Economy: A Study of the Asian Opium Trade 1750-1950. New York: Routledge.

Siamwalla, A. 1978. "Farmers and Middlemen: Aspects of Agricultural Marketing in Thailand," Economic Bulletin for Asia and the Pacific, Vol. 29 (1), p. 38-50.

Singh, N. P. 1980. The East India Company's Monopoly Industries in Bihar: with Particular Reference to Saltpetre and Opium 1773-1833. Muzaffarpur, Bihar: Sarvodaya Vangmaya.

Sinha, N.K. 1956. The Economic History of Bengal: from Plassey to the Permanent Settlement, Vol. I. Calcutta: Firma Mukhopadhyay.

Sinha, N.K. 1968. The Economic History of Bengal: From Plassey to the Permanent Settlement, Volume II. Calcutta: Firma K.L. Mukhopadhyay.

Verelst, H. 1772. A View of the Rise, Progress, and Present State of the English Government in Bengal. London. 
Watts, M. 1994. "Life Under Contract: Contract Farming, Agrarian Restructuring, and Flexible Accumulation," in Peter D. Little and Michael J. Watts eds. Living Under Contract: Contract Farming and Agrarian Transformation in Sub-Saharan Africa, Madison, WI: University of Wisconsin Press.

Williamson, O. 1975. The Economic Institutions of Capitalism, New York: The Free Press.

Wright, H. R. C. 1961. East-Indian Economic Problems in the Age of Cornwallis and Raffles. London: Luzac and EIC Limited. 